\title{
Integrating national and international research, and exploring country-specific factors contributing to work addiction; Commentary to "Workaholism - psychological and social determinants of work addiction"
}

\author{
Paweł Andrzej Atroszko EF, https://orcid.org/0000-0001-5707-3882, \\ Bartosz Atroszko EF, https://orcid.org/0000-0001-8265-1103
}

Faculty of Social Sciences, University of Gdansk, Poland

Keywords: addiction, behavioural addiction, study addiction, work addiction, workaholism

The recent paper by Soroka et al. in Current Problems of Psychiatry constitutes a review of workaholism literature [1]. The review includes the majority of Polish sources $(18 / 23 ; 78 \%)$, which is an important and appreciated effort to summarize some of the significant findings present in the Polish language literature on work addiction. However, there are crucial issues related to the Authors' statements concerning the status of work addiction research that should be addressed. Firstly, the paper is purported to constitute a review of work addiction/workaholism literature, not Polish language literature on the issue. Secondly, the Authors wrote that "Workaholism as a psychological and social phenomenon is the object of only a few empirical studies" (p. 7). In this context, it should be clarified that there are almost 600 papers indexed in Web of Science for the search "work addiction" or "workaholism" [2]. This, for example, constitutes almost $150 \%$ of all papers indexed on obsessive-compulsive personality disorder/anankastic personality disorder/anankastia, which is officially recognized diagnosis for more than a half of a century, and strictly related to work addiction [3]. Of these papers, 39 are indexed as having at least one Polish author, which is among countries with the largest number of publications concerning this issue, following the USA, Netherlands, Italy, Canada, and England. Most of these papers were published in psychological scientific journals as categorized by Web of Science. If only the last five years are considered, there are 25 papers from Polish authors, which is only exceeded by authors from the USA and Italy. Not all of these papers concern results of studies on work addiction; however, a significant portion of them are empirical papers in English from authors frequently publishing on work addiction in international and Polish high-quality journals, as well as in international books $[4,5,6,7,8]$. Furthermore, some Authors frequently publishing on work addiction mostly published in Polish, and these publications include original empirical studies $[9,10,11,12]$.

This relatively high interest in work addiction among Polish researchers probably reflects the fact that compulsive overworking seems to be highly prevalent in Poland. It is significantly more prevalent than in some other countries, perhaps showing two- or three-fold higher rates than in such countries as Norway or Denmark [13]. Its hypothetical precursor in the form of study addiction $[14,15,16]$ is related to significant harm and is already highly prevalent among undergraduate students and high school students in Poland $[14,17,18]$. In large longitudinal cross-cultural studies, study addiction was shown to be temporarily stable and related to work addiction after entering the labor market $[19,20]$. Currently, study addiction, defined as a potential behavioral addiction, is most systematically investigated in Poland.

This strong interest in the consequences of extreme engagement in work in Poland may be related to the fact that, according to the available data, economic success in Poland, and of Poland as a country in recent decades, clearly does not come with an increase in psychological well-being among youngest generations. Macro-level factors such as pressure on economic success may drive work addiction and its consequences on a country level. Work addiction of a parent is related to work addiction 
of a child [21]. It is in recent Polish literature on work addiction that we can find results suggesting that children of work addicts function psychologically worse than children of alcohol addicts or children from incomplete families [22], which parallels findings of systematic studies by Robinson in the 1990s [23]. A recent metaanalysis confirmed that work addiction is related to family dysfunction with significant harm to spouses and children of work addicts [24]. As such, work addiction constitutes a major epidemiological problem, probably of relatively high significance to the Polish population, which requires systematic studies and integrated efforts [3].

Taking into account the prevalence rates of work and study addiction in Poland, perhaps it is not a coincidence that in recent years Poland has experienced a so-called "crisis of child psychiatry", frequent schoolrelated suicides among children and adolescents, and the cultural phenomenon of "patointeligencja" (ang. "pathointelligence"; a portmanteau word made of words "pathological" and "intelligence") related to behavioral and emotional problems among affluent adolescents. The research on the impaired functioning of the latter group typically considered a 'low risk' group is developing for at least two decades showing that the economic success of parents does not make children immune to behavioral problems $[25,26]$. It is currently recognized in the high profile medical literature that improving adolescent health requires improving young people's daily life with families and peers and at schools [27]. Furthermore, risk and protective factors in the social environment at a population level need to be addressed, and more focus on factors that are protective across various health outcomes are required. Contrary to that, studies indicate that the school system focused on narrow success in standardized testing is far from being supportive of children and adolescents [28, 29, 30, 31]. Similarly, pressures from parents on school and academic success are recognized risk factors for psychopathology [32, 33]. This can be arguably traced back to the culture of obsessive productivity and narrow focus on economic success fostering compulsive overworking and overstudying.

A recent debate on work addiction resulted in unprecedented general agreements concerning its current status as a potential behavioral addiction [34]. This debate reflects dynamic advancements in the work addiction field directed toward conceptual clarification of its status [15, $16,35,36,37]$ and recognition as a significant contributor to the global burden of disease [3].One of the main points of this debate is the issue related to misrepresentation of work addiction both in scientific literature and media coverage, not infrequently portraying it as a positive phenomenon and neglecting crucial advancements in the theory and research on this problematic behavior. It is envisaged that this paper will raise awareness, especially among Polish researchers, of the progress made in the field and the importance of work addiction as a psychological and psychiatric problem for the Polish population. It is also highly recommended to integrate efforts among Polish researchers and international experts in the field and create networks of collaboration to conduct high-quality studies on work addiction, including large epidemiological surveys, neuroimaging and biological studies, and clinical trials. Also, publishing results of Polish studies in English (alongside Polish) would allow for integrating findings from Poland with the international body of research on work addiction. This area of research and the general public would benefit from incorporating developments from international literature in the Polish literature and vice versa. It is crucial to present more state-of-the-art research on work addiction within Polish scientific literature and popular press. Simultaneously, one of the challenges is to enable access for international researchers to Polish findings (which in the recent two decades are noteworthy, including regular reports from the Polish Ministry of Health on representative Polish samples [38]). Similar integrations in other countries are highly warranted, as emphasized in the recent debate [34]. There seems to be a substantial body of potentially useful and informative data unintegrated with the international body of research on work addiction.

Finally, substantial differences in prevalence rates of work addiction across countries suggest a significant role of country-specific factors contributing to compulsive overworking. As hinted in this paper, Poland may constitute a specific case as a central European and former communist country that experienced a dynamic, robust economic growth and profound social metamorphoses while developing market economy (curiously, similarly high work addiction prevalence rates are evidenced for another central European post-communist country, Hungary). At present, very little is known and understood concerning how it affected well-being on a population level, and specifically the psychosocial functioning of the youngest generations. It is highly recommended to invest efforts and resources in detailed analyses of the current lamentable state of affairs of many children and adolescents, as well as their parents, and the role of work-related, school-related, and socioeconomic factors affecting it. Particularly, we need to understand and acknowledge the importance of a cult of work, productivity, and economic success, and simultaneously the damaging contribution of unproductive, overwhelming, and evergrowing bureaucracy in eroding social ties and family structures. 


\section{Conflict of interest}

The authors have declared no conflict of interest.

\section{References:}

1. Soroka E, Iwanicka A, Olajossy M. Workaholism - psychological and social determinants of work addiction. Curr Probl Psychiatry, 2020;21(1).

2. Andreassen CS, Schaufeli WB, Pallesen S. Myths about "The myths about work addiction" Commentary on: Ten myths about work addiction (Griffiths et al., 2018). J Behav Addict, 2018; 7: 858-862.

3. Atroszko PA, Demetrovics Z, Griffiths MD. Work addiction, obsessive-compulsive personality disorder, burn-out, and global burden of disease: Implications from the ICD-11. Int J Environ Res Public Health, 2020; 17.

4. Peplińska A, Wojdyło K, Kosakowska-Berezecka N, \& Połomski P. The role of purpose in life and social support in reducing the risk of workaholism among women in Poland. Health Psychol Rep, 2015;3: 326-335.

5. Malinowska D, Tokarz A, Wardzichowska A. Job autonomy in relation to work engagement and workaholism: Mediation of autonomous and controlled work motivation. Int J Occup Med Environ Health, 2018; 31: 445-458.

6. Chodkiewicz J, Hauk M. The role of a tool in measuring negative consequences of workaholism. Med Pr, 2016; 67: 467-476.

7. Kirkcaldy B, Malinowska D, Staszczyk S, Tokarz A. A scheme for workaholism intervention including cognitive, affective and behavioural techniques. In: Antoniou A-S, Cooper CL eds., Coping, personality and the workplace: Responding to psychological crisis and critical events. Gower; Routledge: 2015.

8. Kunecka D, Hundert M. The extent of workaholism in a group of Polish nurses. Int J Health Plann Manage, 2019; 34.

9. Golińska L. Pracoholizm: uzależnienie czy pasja. Centrum Doradztwa i Informacji Difin: 2009.

10. Szpitalak M. Wielowymiarowy kwestionariusz oceny pracoholizmu. Kraków; Wydawnictwo Uniwersytetu Jagiellońskiego: 2012.

11. Dudek B, Hauk M, Merecz D. Ocena pracoholizmu jako behawioralnej tendencji - polska adaptacja Kwestionariusza Mudracka i Naughtona. Med Pr, 2011; 62: 127.

12. Paluchowski WJ, Hornowska E, Haładziński P, Kaczmarek L. Czy praca szkodzi? Wyniki badań nad kwestionariuszem nadmiernego obciążania się pracą. Warszawa; Wydawnictwo Naukowe Sholar: 2014: 24-41.

13. Atroszko PA, Pallesen S, Griffiths MD, Andreassen CS. Work addiction in Poland: Adaptation of the Bergen Work Addiction Scale and relationship with psychopathology. Health Psychol Rep, 2017; 5: 345-355.

14. Atroszko PA. The structure of study addiction: Selected risk factors and the relationship with stress, stress coping and psychosocial functioning(Unpublished doctoral thesis). University of Gdansk; Poland: 2015.

15. Atroszko PA. Commentary on: The Bergen Study Addiction Scale: psychometric properties of the Italian version. A pilot study. Theoretical and methodological issues in the research on study addiction with relevance to the debate on conceptualising behavioural addictions. Psychiatr i Psychol Klin, 2018; 18: 276282.

16. Atroszko PA. Response to: Loscalzo and Giannini (2018). A boon of incoherence: insights on the relationship between study/ work addiction and obsessive-compulsive personality disorder.
Psychiatr i Psychol Klin, 2019; 19: 237-243.

17. Lawendowski R, Bereznowski P, Wróbel WK, Kierzkowski M, Atroszko PA. Study addiction among musicians: Measurement, and relationship with personality, social anxiety, performance and psychosocial functioning. Music Sci, 2019.

18. Wróbel WK. Study addiction among high school students: Measurement and relationship with psychopathology, personality, quality of life, and school variables(Unpublished master's thesis). University of Gdańsk; Poland: 2020.

19. Atroszko PA, Andreassen CS, Griffiths MD, Pallesen S. The relationship between study addiction and work addiction: A cross-cultural longitudinal study. J Behav Addict, 2016; 5: 708714 .

20. Atroszko PA, Andreassen CS, Griffiths MD, Pallesen S. Study addiction: A cross-cultural longitudinal study examining temporal stability and predictors of its changes. J Behav Addict, 2016; 5: 357-362.

21. Kravina L, Falco A, De Carlo NA, Andreassen CS, Pallesen S. Workaholism and work engagement in the family: The relationship between parents and children as a risk factor. Eur J Work Organ Psychol, 2014; 23: 875-883.

22. Polok G, Szromek AR, Krannich M, Wybrańczyk K. Wpływ uzależnienia od pracy zawodowej, rozpadu rodziny oraz alkoholizmu na współistniejące zachowania wśród osób do 35 roku życia. Zeszyty Naukowe. Organizacja i Zarządzanie/ Politechnika Śląska, 2018; 131: 453-465.

23. Robinson BE.Chained to the desk: A guidebook for workaholics, their partners and children, and the clinicians who treat them. New York; University Press: 2014.

24. Clark MA, Michel JS, Zhdanova L, Pui SY, Baltes BB. All work and no play? A meta-analytic examination of the correlates and outcomes of workaholism. J Manage, 2016; 42: 1836-1873.

25. Luthar SS, Becker, B.E. Privileged but pressured? A study of affluent youth. Child Dev, 2002; 73: 1593-1610.

26. Hanson MD, Chen E. Socioeconomic status and health behaviors in adolescence: A review of the literature. J Behav Med, 2007; 30: 263-285.

27. Viner RM, Ozer EM, Denny S, Marmot M, Resnick M, Fatusi A, et al. Adolescence and the social determinants of health. Lancet, 2012; 379: 1641-1652.

28. Abeles V. Beyond measure: Rescuing an overscheduled, overtested, underestimated generation. New York; Simon \& Schuster: 2015.

29. Mulholland Q. The case against standardized testing. Harvard Political Rev, 2015, May 14. Retrieved from http:// harvardpolitics.com/united-states/case-standardized-testing/

30. Klus-Stańska D.Walka o testo-maniakalne przetrwanie, czyli po co i czego uczą się przyszli polscy nauczyciele?Rocznik Pedagogiczny, 2017;40: 71-87.

31. Melosik Z. Wskaźnikowanie człowieka i rzeczywistości jako forma sprawowania władzy.Przegląd Pedagogiczny, 2016;2: 243-253.

32. Bor W, Dean AJ, Najman J, Hayatbakhsh R. Are child and adolescent mental health problems increasing in the 21st century? A systematic review. Australian \& New Zealand Journal of Psychiatry, 2014; 48: 606-616.

33. Klinger, DA., Freeman, JG, Bilz L, Liiv K, Ramelow D, Sebok SS, et al.Cross-national trends in perceived school pressure by gender and age from 1994 to 2010. The European Journal of Public Health, 2015; 25: 51-56.

34. Atroszko PA., Demetrovics Z, Griffiths MD. Beyond the myths about work addiction: Toward a consensus on definition and trajectories for future studies on problematic overworking: A response to the commentaries on: Ten myths about work 
addiction (Griffiths et al., 2018). Journal of Behavioral Addictions, 2019; 8: 7-15.

35. Atroszko PA. Work addiction as a behavioural addiction: Towards a valid identification of problematic behaviour. Australian \& New Zealand Journal of Psychiatry, 2019; 53: 284285.

36. Atroszko PA, \& Griffiths MD. Work addiction is not new to the psychological literature and has evolved over time. Global Journal of Addiction \& Rehabilitation Medicine, 2017; 3: 1-2.

37. Griffiths MD, Demetrovics Z, Atroszko PA. Ten myths about work addiction. Journal of Behavioral Addictions, 2018;7: 845-857.

38. Moskalewicz J, Badora B, Feliksiak M, Głowacki A, Gwiazda M, Herrmann M., et al. Oszacowanie rozpowszechnienia oraz identyfikacja czynników ryzyka i czynników chroniących hazardu i innych uzależnień behawioralnych - edycja 2018/2019. Warszawa; Polish Ministry of Health: 2019.

\section{Corresponding author}

Paweł Andrzej Atroszko Institute of Psychology University of Gdańsk

Bażyńskiego 4

80-309 Gdańsk

Poland

Phone: +48585234322

e-mail: p.atroszko@ug.edu.pl

Otrzymano: 28.10.2020

Zrecenzowano: 12.11.2020

Przyjęto to druku: 11.01.2021 